\title{
Formal Finance, Informal Finance and Private Listed Enterprises' Bank Loan Defaults
}

\author{
Wei Wang \\ School of Economics and Management \\ Southwest Jiaotong University \\ Cheng du, China \\ E-mail: yifengwww@aliyun.com
}

\begin{abstract}
In this paper, the effect of formal finance and informal finance on bank loan defaults of private enterprises are examined by Logistic regression. The results showed that: First, the higher the level of the formal financial development, the lower the default rate of bank loan of the private enterprises in the region. Second, the higher the level of the informal financial development in the region, the lower the bank loan default rate of the private enterprises in the region. Third, in areas with higher levels of formal financial development, financial institutions can just control the quality of loans, thereby reducing the default of bank loans of private enterprises. Fourth, in areas with high level of informal financial development, informal finance to give private enterprise financing convenience, more to meet the demand for funds, so as to reduce the demand of the private enterprise to bank loans, thereby reducing the loan default. Fifth, these results enrich the study of the relationship both formal finance and informal finance between fast private enterprise developments in the China, and also provide theoretical and empirical basis for further promoting the standardization of corporate financing behavior and promoting the healthy development of the capital market.
\end{abstract}

Keywords- Private Listed Enterprises; Formal Finance; Informal Finance; Bank Loan; Loan Defaults.

\section{INTRODUCTION}

Since the reform and opening up for 30 years, China's economy has maintained a rapid growth for many years and attracted worldwide attention. Private economy is increasingly becoming the engine of economic growth. Private enterprises in terms of quantity has accounted for more than $90 \%$ of the national total number of enterprises, the total output value of private enterprises has accounted for about $50 \%$ of the country's GDP, taxes on private economy accounted for nearly half of the total amount of tax and private economy impetus employment has accounted for more than $75 \%$ of new jobs ${ }^{[1]}$. It can be seen that the role of the private economy to promote the development of China is not only in the economy. With the increase in the number of private enterprises and the increase in the proportion of private economy in the national product, its social functions are gradually highlighted.

With the rapid development of enterprises, external financing has gradually become the main financing channels for enterprises. The empirical results show that external financing is an important factor affecting the development of enterprises. The rapid development of private enterprises in the China, it is necessary to also do not leave the support of external financing. Capital market in the China has not been able to effectively ease the financing needs of private enterprises. Similarly, private enterprises occupy in the bond market share is almost zero $^{[2]}$. In this case, the development of private enterprises in the capital needs, on the one hand, by actively seeking formal financial loans, on the other hand rely on informal financing channels to meet.

In this paper, the Logistic regression of the dummy variable Violate as the dependent variable of the bank loan is paid on time by the private enterprises in the China, in order to examine the influence of the different levels of the different development level of the regional formal finance and informal finance on the external financing of private enterprises.

\section{THEORETICAL ANALYSIS AND RESEARCH HYPOTHESIS}

The level of formal financial development has an important impact on the enterprise to obtain debt financing. In the high level of financial development reg ion, the bank can effectively acquire and transfer information related to business loans related. Therefore, it can effectively evaluate the quality of enterprises to invest in the project, according to the information, and reasonable to the enterprise loans. In the areas with low level of financial development, the problem of information asymmetry is relatively serious, so that the possibility of external financing is lower. Therefore, the improvement of the level of financial development is conducive to the enterprise to get more bank loans, but also conducive to the quality of bank loans, so as to reduce the default rate. Beck et al. $(2004)^{[3]}$ and Mitton $(2008)^{[4]}$ to provide evidence for this. So researchers put forward the following hypothesis:

Hypothesis 1: the higher the level of the formal financial development, the better the quality of the formal financial control over the loan, and thus the lower the default rate of bank loans of private enterprises.

The phenomenon of the coexistence of formal finance and informal finance is the market segmentation phenomenon caused by information asymmetry in financial markets. In dealing with the information asymmetry of private enterprises, the private finance has the advantage of information. Lin Yifu and Sun Xifang $(2005)^{[5]}$ found that due to the small and medium-sized enterprise information opaque and failure in providing sufficient guarantee or mortgage, it is difficult for formal 
financial institutions to effectively overcome information asymmetry caused by the adverse selection problem, rather than formal finance in the collection of small and medium enterprises "soft information has advantages. Hoff and Stiglitz (1990) ${ }^{[6]}$ explains that information asymmetry is the main obstacle for the SMEs and the informal finance. In order to reduce the risk, the formal financial choice credit rationing of poor quality loans were reluctant to part of the loan form of credit capital gap, small and mediumsized enterprises in the regular financing cannot meet the financing needs of transforming into private finance. Based on the above analysis, this paper puts forward the following hypothesis to verify:

Hypothes is 2A: area folk finance development level is high, the private enterprise is more easily from the informal financing channels to obtain funds, which can timely repayment of bank loans and bank loan default rate is low;

Hypothesis 2B: area folk finance development level is high, and the private enterprise is more easily from the informal financing channels to obtain funds, thereby reducing the need for bank loans, reducing the bank loan default rates.

\section{DAT A AND RESEARCH METHODS}

\section{A. Sample Selection and Data Sources}

This paper takes 2006-2011 years listed in Shanghai and Shenzhen Stock Exchange private enterprises as the research sample. According to the following principles to eliminate some samples:

(1) Excluding financial sector sample, because the liabilities of financial industry enterprises are different from that of non-financial industry enterprises;

(2) Removing during 2006-2011, either by ST, PT treatment enterprises;

(3) Excluding the lack of data and sample data extremely unusual;

Finally, the sample consisted of 245 firms between the2006-2011, a total of 1345 observations.

\section{B. Model Set and Variable Definition}

Researchers refer to Chen Deqiu et al. (2013) ${ }^{[7]}$ definition method, through consulting the report of the annual report of the enterprise information, to determine whether the company was on time to repay bank loans. If corporate disclosure has been due not repay, then the default dummy variables Violate value is 1 , otherwise a value of 0 , then the dependent variable logistic regression as Violate. In order to test hypothes is 1, 2, researchers will be tested regression equation were set as:

Violate $=\alpha+\beta_{1}$ Zgjf $+\beta_{2} X+\beta_{3}$ Industry $+\beta_{4}$ Year $+\varepsilon$

Violate $=\alpha+\beta_{1}$ Mjrz $+\beta_{2} X+\beta_{3}$ Industry $+\beta_{4}$ Year $+\varepsilon$

In equation (1) and (2), related indicators researchers use Wang Xiaolu's Business Environment Index for China's Provinces 2011Report. Zgjf indicator from the financial services index, according to the definition of Wang Xiaolu et al, the larger the index, means the banking sector are more likely to make lending decisions based on the economic principle, the extra cost of the loan is low. Mjrz indicates the degree of difficulty of private enterprise to obtain funds from the area. Mjrz is taken from one of the "private financing" index, according to Wang Xiaolu definition, the greater the index, which means that companies are more likely to raise funds from the local private channels.

$\mathrm{X}$ is a vector formed by a plurality of control variables, researchers controlled for a number of factors that affect enterprise debt financing: Enterprise Scale (Size), Profitability (ROE), Growth (Growth), Mortgage Assets (Assetstruc), the Proportion of the First Shareholder (Shrcrl), Non-Debt Tax Shield (Ndts), Free Cash Flow (Fcf), Tobin's Q (TQ). Researchers Researchers also consider the industry attributes (Industry) and annual (year) may affect the financing on corporate debt ${ }^{[8-9]}$.

\section{EMPIRICAL RESULTS AND ANALYSIS}

\section{A. Descriptive Statistics of Variables}

The variables were analyzed by descriptive statistics of the level of the development of folk finance, and the difference between the two groups was compared with the "independent sample $t$ test". The results showed that the folk financial development group with higher debt together (Fuzaihj) at the 5\% level was significantly higher than that of the development of the lower group; but the amount of bank loans (Structure) at the 10\% level, proportion of long-term loans (Matrity) at the level of 5\%, obviously lower than that of development of the lower group. This shows that the higher level of private financial development in the region, although the total private enterprise liabilities higher, but the amount of bank loans and long-term loans are all less.

TABLE I. DESCRIPTIVE STATISTICS

\begin{tabular}{|c|c|c|c|c|c|c|c|}
\hline & \multicolumn{3}{|c|}{$\begin{array}{c}\text { Higher levels of folkfinancing } \\
\text { development } \\
(\mathrm{N}=677)\end{array}$} & \multicolumn{3}{|c|}{$\begin{array}{c}\text { Lowlevel of development of } \\
\text { folkfinancing } \\
(\mathrm{N}=\mathbf{6 8 8})\end{array}$} & \multirow{2}{*}{$\begin{array}{c}\text { Mean } \\
\text { comparison } \\
\text { T-Value } \\
\end{array}$} \\
\hline & Min & Mean & Mix & Min & Mean & Mix & \\
\hline Fuzaihj & 0.031 & 0512 & 0.917 & 0.068 & 0.497 & 0.886 & $1.788^{*}$ \\
\hline Structure & 0.007 & 0.467 & 0.878 & 0.007 & 0.483 & 0.878 & $-1.696^{*}$ \\
\hline Matrity & 0 & 0225 & 1 & 0 & 0262 & & $-2.469 * *$ \\
\hline
\end{tabular}

Note: Fuzaihj=t otal enterprise liability/total assets; Structure=total bank loans/total assets; Matrity=bank long-term loans/Total bank loans.

\section{B. Multiple Regression Results}

Researchers put the formal finance, the informal finance and the interaction among them in order to get (1), $(2),(3),(4)$ results of the Logistic regression. Model (1), (2), (3) respectively suggest that the formal finance (value larger mean from the bank loans more easily, additional costs less), informal finance (the bigger the value is, the easier the financing from the private channels), have a significant negative correlation at $1 \%$ level with private enterprises loan default rate. This means that not only in the formal financial development in areas with better, because the improvement of the market operation ability of the bank to reduce the loan default rates, and in the folk financial development of higher areas, can also reduce private enterprises loan default rates. But they might have different mechanisms of action, higher levels of formal financial development, bank according to market operation ability is stronger, the on loan risk control is better, thereby lending default rate is lower. Folk financial development 
level is high, private enterprises more easily from the folk financing, and from two aspects of reducing enterprise loan default, is on the one hand, private enterprise financing amount is limited, firms are more likely to from private financing, the demand for bank loans is reduced and loan defaults is reduced. On the other hand, although there is no decrease in the demand of private enterprises on the amount of bank loans, but because private enterprises more easily from the folk financing, the enterprises have more funds to repay the maturity of bank loans, thereby reducing the loan default rate.

In order to further clarify the role of formal finance and private banking to reduce the default of bank loans in private enterprises, researchers analyze the interaction between them. Interaction variables (Zgjr*Mjrze) as indicated by the lower folk financial level dummy variables (Mjrze) (higher than the median 0 that is at or below the median of 1) with formal financial (Zgjr) multiplied, the coefficient is positive, and at the level of $1 \%$ highly significant. At the same time, formal finance (Zgjr) at the $10 \%$ level still is significantly negative, which means that, although the company is located in an area with relatively high levels of bank development, market operation ability is strong, to loan risk control is better, but folk financial development level lower, the enterprises from the folk financing more difficult, the bank loan default will be higher.

Interaction variables (Mjrz*Zgjre) as indicated by the lower of the formal financial dummy variables Zgjre (higher than the median 0 that is at or below the median of 1) with private finance (Mjrz) multiplied, the loan default rate $10 \%$ level is significantly negative. Also, private finance (Mjrz) is still at the $1 \%$ level significantly for negative, illustrate this, although the company is located in an area with bank development level is low, market operation ability is weaker, loan risk of poor of control, but the folk finance development level is high, firms are more likely to from the folk financing, bank loan defaults rate lower. The results show that the formal finance and informal finance have significantly negative correlation to the bank loan default rate, but their mechanism is not the same. Formal finance is from the loan itself quality control its default rate; private finance is in order to meet the funding needs of private enterprises, thereby reducing the demand for bank loans or to make the timely repayment of bank loans, thereby reducing the loan default rates.
TABLE II. FORMAL FINANCE, INFORMAL FINANCE AND PRIVATE ENTERPRISE LOAN DEFAULT

\begin{tabular}{|c|c|c|c|c|}
\hline & \multicolumn{4}{|c|}{$\begin{array}{c}\text { Bank loan default } \\
\text { (Violate) }\end{array}$} \\
\hline & (1) & (2) & (3) & (4) \\
\hline Intercept & 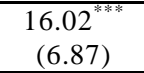 & $\begin{array}{l}17.56^{\text {*3*3\% }} \\
(7.30)\end{array}$ & $\begin{array}{l}15.06^{\text {***3* }} \\
(6.37)\end{array}$ & 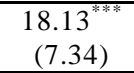 \\
\hline Jrfw & & & & \\
\hline Zgjr & $\begin{array}{l}-0.765^{* * *} \\
(-2.72)\end{array}$ & & $\begin{array}{l}-0.405^{*} \\
(-1.71)\end{array}$ & \\
\hline Mjrz & & $\begin{array}{r}-1.477 \\
(-4.16)\end{array}$ & & $\begin{array}{r}-1.606 \\
(-3.92)\end{array}$ \\
\hline Zgjr*Mjrze & & & $\begin{array}{c}0.219^{* * * * 6} \\
(2.71)\end{array}$ & \\
\hline Mjrz*Zgjre & & & & $\begin{array}{r}-0.0625^{*} \\
(-1.68)\end{array}$ \\
\hline Size & $\begin{array}{l}-0.739 \\
(-6.65)\end{array}$ & $\begin{array}{r}-0.713 \\
(-6.41)\end{array}$ & $\begin{array}{l}-0.755^{2} \\
(-6.72)\end{array}$ & $\begin{array}{l}-0.718 \\
(-6.47)\end{array}$ \\
\hline Growth & $\begin{array}{c}-0.0184 \\
(-0.69)\end{array}$ & $\begin{array}{c}-0.0194 \\
(-0.71)\end{array}$ & $\begin{array}{c}-0.0159 \\
(-0.60)\end{array}$ & $\begin{array}{c}-0.0190 \\
(-0.69)\end{array}$ \\
\hline Roe & $\begin{array}{l}-0.492 \\
(-0.41)\end{array}$ & $\begin{array}{l}-0.702 \\
(-0.58)\end{array}$ & $\begin{array}{l}-0.684 \\
(-0.58)\end{array}$ & $\begin{array}{l}-0.713 \\
(-0.58)\end{array}$ \\
\hline Assetstruc & $\begin{array}{l}0.585 \\
(0.81)\end{array}$ & $\begin{array}{l}0.371 \\
(0.51)\end{array}$ & $\begin{array}{l}0.441 \\
(0.59)\end{array}$ & $\begin{array}{l}0.433 \\
(0.59)\end{array}$ \\
\hline Ndts & $\begin{array}{l}-23.79^{* * *} \\
(-2.22)\end{array}$ & $\begin{array}{l}-21.07^{*} \\
(-1.92)\end{array}$ & $\begin{array}{l}-21.29^{*} \\
(-1.95)\end{array}$ & $\begin{array}{l}-21.59^{* *} \\
(-1.98)\end{array}$ \\
\hline Fcf & $\begin{array}{l}-3.228 \\
(-1.32)\end{array}$ & $\begin{array}{l}-3.213 \\
(-1.30)\end{array}$ & $\begin{array}{l}-3.311 \\
(-1.33)\end{array}$ & $\begin{array}{l}-3.144 \\
(-1.27)\end{array}$ \\
\hline Shrcrl & $\begin{array}{c}0.00190 \\
(0.24) \\
\end{array}$ & $\begin{array}{c}0.00148 \\
(0.19) \\
\end{array}$ & $\begin{array}{c}0.00207 \\
(0.26) \\
\end{array}$ & $\begin{array}{c}0.00145 \\
(0.18) \\
\end{array}$ \\
\hline TQ & $\begin{array}{c}0.00548^{* * *} \\
(2.52)\end{array}$ & $\begin{array}{c}0.00533^{* *} \\
(2.34)\end{array}$ & $\begin{array}{c}0.00498^{* *} \\
(2.19)\end{array}$ & $\begin{array}{c}0.00512^{* *} \\
(2.24)\end{array}$ \\
\hline Industry & Yes & Yes & Yes & Yes \\
\hline Year & No & No & No & No \\
\hline $\mathrm{N}$ & 1345 & 1345 & 1345 & 1345 \\
\hline Pseudo $\mathrm{R}^{2}$ & 0.1024 & 0.1162 & 0.1099 & 0.1168 \\
\hline $\begin{array}{l}\text { Log } \\
\text { likelihood }\end{array}$ & -437.9780 & -431.2418 & -434.3179 & -430.9433 \\
\hline
\end{tabular}

Therefore, the informal finance is through the reduction of private enterprise's Bank loan demand, or by making the private enterprise can repay bank loans in time to reduce the loan defaults?

From Table 1 to informal financial development level packet (higher than the median for a group, is at or below the median for another set) descriptive results show, folk financial development level is high in the group of liabilities together at the $5 \%$ level, significantly higher than that of developing low group, and folk financial development level is high in the group's total bank loans at the $1 \%$ level, the proportion of long-term loans at the level of $10 \%$, significantly lower than the development of the lower group. This shows that the level of private financial development in the region, private enterprises in total debt higher, but the total bank loans less, the proportion of longterm loans is also shorter. This means that private finance is by giving private enterprises to provide financing convenience, more to meet corporate demand for funds, thereby reducing the demand for bank loans, thereby reducing the loan default rates. Also shows that the informal finance as a complementary form of a kind of social credit, finance and formal there are reciprocal substitution effect ${ }^{[10]}$. 


\section{CONCLUSIONS}

In this paper, the effect of formal finance and informal finance on bank loan defaults of private enterprises is examined by Logistic regression. The results showed that the area of formal financial development level is high, within the area of private enterprise bank loan default rate is low; region of the folk financial development level is high, the region private enterprise bank loan default rate is low; area of the formal financial development level is higher, the financial institutions is from quality control lending itself to control private enterprise bank loan default, and in the folk financial development level is higher, folk finance through to provide financing convenience to private enterprises, more to meet the demand for funds, so as to reduce the private enterprise demand for bank loans, thereby reducing the loan default.

Policy implications of this research is as following: (1) to further promote the market-oriented reform, further reduce improper government intervention, establish the fair competition mechanis m of enterprises, give full play to the basic role of the market in the allocation of resources; (2) to speed up financial innovation, promote marketoriented interest rate reform, interest rate deregulation, let the market determine the supply and demand of funds the interest rate level, further improve the information exchange platform for the financial industry, alleviate the information asymmetry of both lending and the adverse selection and moral hazard problems, improve the external financing environment of private enterprises; (3) to establish and improve re levant laws and regulations, create a favorable legal environment, ensure that "according to the law, the law must be strictly enforced, and law breakers must be prosecuted", fully protect the legitimate rights and interests of owners, to provide a good legal environment for market competition; (4) to build a credit society, a sound credit guarantee mechanism, improve the construction of enterprise credit system, realize information sharing, and let the creditors through enterprise credit system query details of the debtor, in order to reduce the potential risks. At the same time, a sound credit guarantee mechanism, the establishment of a credit guarantee fund to compensate for the loss of risk.
There are still some limitations of this study: (1) based on the Shanghai and Shenzhen two city listed private enterprise as the research sample, and the listed corporation is a special type of enterprise groups, the research conclusion of this paper may not be extended to unlisted private enterprises; (2)because of the limited information, researchers have to separate the real part belongs to the folk financing from the enterprise debt financing, and could not be its impact on the financing of private enterprises to make more in-depth analysis; (3) this paper demonstrates the formal finance, informal finance of bank loans to private enterprises have an important impact on default, but it does not matter between the two is about them how there is a relationship between each other, and what kind of impact.

\section{REFERENCES}

[1] Du Xingqiang, Guo Jianhua, Lei Yu, Political Connections and Private Enterprise Donation: Measurement Methods and Empirical Evidence[J]. Finance and Trade Research, 2010 (1): 89-99.

[2] Luo Danglun, Zhen Liming, Private control, political relationship and enterprise financing constraints -- Based on empirical evidence from Chinese private listing Corporation [J]. Financial Research, 2008,342 (12): 164-178.

[3] Beck T., Demirgüç-Kunt A., Maksimovic V.. Financing patterns around the world: Are small firms different?[J]. Journal of Financial Economics,2008,89(3):467-487.

[4] Mitton T.. Why Have Debt Ratios Increased for Firms in Emerging Markets?[J]. European Financial Management,2008,14(1): 127-151.

[5] Lin Yifu, Sun Xifang. Information, informal finance and SME financing [J]. Economic Research, 2005 (7): 35-44.

[6] K. Hoff, J. Stigliz. Imperfect Information and Rural Credit Markets: Puzzles and Policy Perspectives[J]. World Bank Economic Review, 1990,4(3):235-250.

[7] Chen Deqiu, Xiao Zezhong, Dong Zhiyong. Family control structure and bank credit contract: rent seeking or efficiency?[J]. Management World.2013 (9):130-143.

[8] DemirgüÇ-Kunt A., Maksimovic V.. Law, finance and firm growth[J]. Journal of Finance, 1998,53(6):2107 -2137.

[9] Rajan R., L. Zingales, What DoResearchers researchers Know about Capital Structure? Some Evidence from International Data[J]. Journal of Finance, 1995(50):1421-1460.

[10] Gao Xiaoqiong. Institutional background, economic operation and private lending[J]. Financial Research, 2004 (12): 135-139. 